\title{
Hospital-acquired infections caused by enterococci: a systematic review and meta-analysis, WHO European Region, 1 January 2010 to 4 February 2020
}

Simon Brinkwirth ${ }^{1}$, Olaniyi Ayobami ${ }^{1}$, Tim Eckmanns ${ }^{1}$, Robby Markwart ${ }^{1,2}$

1. Unit 37: Nosocomial Infections, Surveillance of Antimicrobial Resistance and Consumption, Robert Koch Institute, Berlin, Germany

2. Jena University Hospital, Institute of General Practice and Family Medicine, Jena, Germany

* These authors contributed equally to this article and share last authorship

Correspondence: Robby Markwart (robby.markwart@med.uni-jena.de)

Citation style for this article:

Brinkwirth Simon, Ayobami Olaniyi, Eckmanns Tim, Markwart Robby. Hospital-acquired infections caused by enterococci: a systematic review and meta-analysis, WHO European Region, 1 January 2010 to 4 February 2020. Euro Surveill. 2021;26(45):pii=2001628. https://doi.org/10.2807/1560-7917.ES.2021.26.45.2001628

Background: Hospital-acquired infections (HAI) caused by Enterococcus spp., especially vancomycinresistant Enterococcusspp. (VRE), are of rising concern. Aim: We summarised data on incidence, mortality and proportion of HAl caused by enterococci in the World Health Organization European Region. Methods: We searched Medline and Embase for articles published between 1 January 2010 and 4 February 2020. Random-effects meta-analyses were performed to obtain pooled estimates. Results: We included 75 studies. Enterococcus spp. and VRE accounted for $10.9 \%$ (95\% confidence interval $(\mathrm{CI}): 8.7-13.4$; range: 6.1-17.5) and $1.1 \%$ (95\% Cl: $0.21-2.7$; range: $0.39-$ 2.0) of all pathogens isolated from patients with HAI. Hospital wide, the pooled incidence of HAl caused by Enterococcus spp. ranged between 0.7 and $\mathbf{2 4 . 8}$ cases per 1,000 patients (pooled estimate: 6.9; $95 \%$ $\mathrm{Cl}$ : 0.76-19.0). In intensive care units (ICU), pooled incidence of $\mathrm{HAl}$ caused by Enterococcus spp. and VRE was 9.6 (95\% Cl: 6.3-13.5; range: 0.39-36.0) and 2.6 (95\% Cl: $0.53-5.8$; range: $0-9.7$ ). Hospital wide, the pooled vancomycin resistance proportion among Enterococcus spp. HAl isolates was 7.3\% (95\% Cl: $1.5-16.3$; range: $2.6-11.5)$. In ICU, this proportion was $11.5 \%$ (95\% Cl: 4.7-20.1; range: 0-40.0). Among patients with hospital-acquired bloodstream infections with Enterococcus spp., pooled all-cause mortality was $21.9 \%$ (95\% Cl: $15.7-28.9$; range: $14.3-$ 32.3); whereas all-cause mortality attributable to VRE was $33.5 \%$ (95\% Cl: 13.0-57.3; range: $14 \cdot 3-41.3$ ). Conclusions: Infections caused by Enterococcus spp. are frequently identified among hospital patients and associated with high mortality.

\section{Introduction}

Enterococcus spp. is a genus of Gram-positive, facultative anaerobic, catalase-negative bacteria that commonly inhabit the intestinal tracts of healthy humans and animals [1]. In addition to their role as commensals, enterococci are known for being associated with hospital-acquired infections. They can cause a wide range of infections, including infections of the urinary tract, bloodstream, and endocardium [2]. Enterococci, particularly E. faecalis and E. faecium, are among the most frequently isolated pathogens from patients with hospital-acquired infections (HAl) $[1,3,4]$. Hospital-acquired infections with enterococci are associated with considerable mortality [5-7], morbidity [8,9] and economic burden [10]. The clinical relevance of Enterococcus spp. is emphasised by their intrinsically low susceptibility to a wide range of antimicrobial drugs, including aminoglycosides, cephalosporins and sulphonamides and in the case of $E$. faecium, low-dose penicillin and ampicillin $[11,12]$. In view of the dwindling number of treatment options, vancomycin is commonly used to treat enterococcal infections, especially $E$. faecium. After the introduction of vancomycin in 1958 [13], a profound increase in prescriptions was recorded in the early 1980s [14]. Consequently, the first vancomycin resistance in clinical Enterococcus spp. isolates was observed in 1988 in London, United Kingdom [15]. Since then, vancomycinresistant Enterococcus spp. (VRE) has spread and been detected in healthcare facilities across the world [16]. A rise of vancomycin resistance has been observed in clinical Enterococcus spp. isolates (especially in E. faecium) in many European countries in the last decade 
Study selection criteria

Studies were included if they met all of the following criteria:

- The study provided data for at least one of the predefined primary outcomes for Enterococcus spp. and/or E. faecium. Studies were only included if they provided microbiological results where either the pathogen was identified or the culture was negative for more than $90 \%$ of all HAl episodes.

- The study was conducted in the WHO European Region.

- Data collection was completed before 2008 and the study was published after 2009.

- The hospital-acquired infections were defined according to appropriate definitions (e.g. US CDC/NHSN [99,100]).

- A largely unselected patient cohort was studied, i.e. not only high-risk patients such as low birthweight neonates or elderly patients, etc. or those with a specific underlying disease.

- The study was published in English, French, German or Spanish.

- Only studies that reported data for total HAI and HA-BSI were included.

Studies were excluded if:

- Data was provided for HAl outside of hospitals, such as nursing homes.

- Studies with any of the following study designs were excluded: literature reviews, intervention studies, case-control studies, outbreak studies and case series.

HAI: hospital-acquired infections; HA-BSI: hospital-acquired bloodstream infections; NHSN: National Healthcare Safety Network US CDC: United States Centers for Disease Control and Prevention; WHO: World Health Organization.

in particular $[17,18]$. A population-based study showed that there were ca 16,000 nosocomial VRE infections with 1,065 attributable deaths in the European Union/ European Economic Area in 2015, nearly twice as many as reported in 2007 [19]. Aggregated data show that up to $55 \%$ of all $\mathrm{HAl}$ could be prevented by implementing multilevel infection prevention and control measures [20], potentially supporting a substantial reduction of the prevalence and mortality of enterococcal HAI. However, to our knowledge, no systematic review on the burden of $\mathrm{HAl}$ with Enterococcus spp., including vancomycin-resistant strains, in Europe has been published yet.

Systematic data on the epidemiology of enterococcal HAl are needed to fully estimate and understand the epidemiology of Enterococcus spp. infections. We therefore conducted a systematic review and metaanalysis to determine the prevalence, incidence and mortality as well as vancomycin resistance proportions of hospital-acquired Enterococcus spp. infections in the World Health Organization (WHO) European Region.

\section{Methods}

We conducted this systematic review according to a protocol published a priori in the Prospective Register for Systematic Reviews (PROSPERO, 2020 CRD42020166863) and followed the reporting guidelines from the Preferred Reporting Items for Systematic Reviews and Meta-Analyses (PRISMA) statement [21].

\section{Study outcomes}

The primary outcomes of this review are the prevalence, incidence and incidence density of hospital-acquired Enterococcus spp./E. faecium and VRE / vancomycin-resistant E. faecium (VREF) infections among hospitalised patients and at the population level. Incidence density is defined as new cases per 1,000 patient hospitalisation days. The mortality of patients with HAl caused by Enterococcus spp./E. faecium and VRE/ VREF was additionally studied as a primary outcome. Secondary outcomes are (i) the proportion of vancomycin resistance among all Enterococcus spp. / E. faecium $\mathrm{HAl}$ isolates and; (ii) the proportion of HAl with Enterococcus spp. / E. faecium and VRE/VREF among all identified microorganisms from patients with HAI. In our review, cases of HAl caused by Enterococcus spp. / E. faecium include both vancomycin-resistant and sensitive strains.

\section{Search strategy, study selection criteria and data extraction}

We searched Medline and Embase for epidemiological and surveillance studies reporting data on HAl. The search was carried out for studies published between 1 January 2010 and 4 February 2020 without any language restrictions. This timeframe was chosen because we aimed to summarise recent data on the epidemiology of hospital-acquired Enterococcus spp., especially given the rise of vancomycin resistance in Europe in the last decade. The detailed search strategy, including search strings, is provided in Supplementary Material. Title, abstract and full-text screening were 
PRISMA flowchart of included studies on hospital-acquired infections caused by enterococci, WHO European Region, 1 January 2010-4 February $2020(\mathrm{n}=75)$

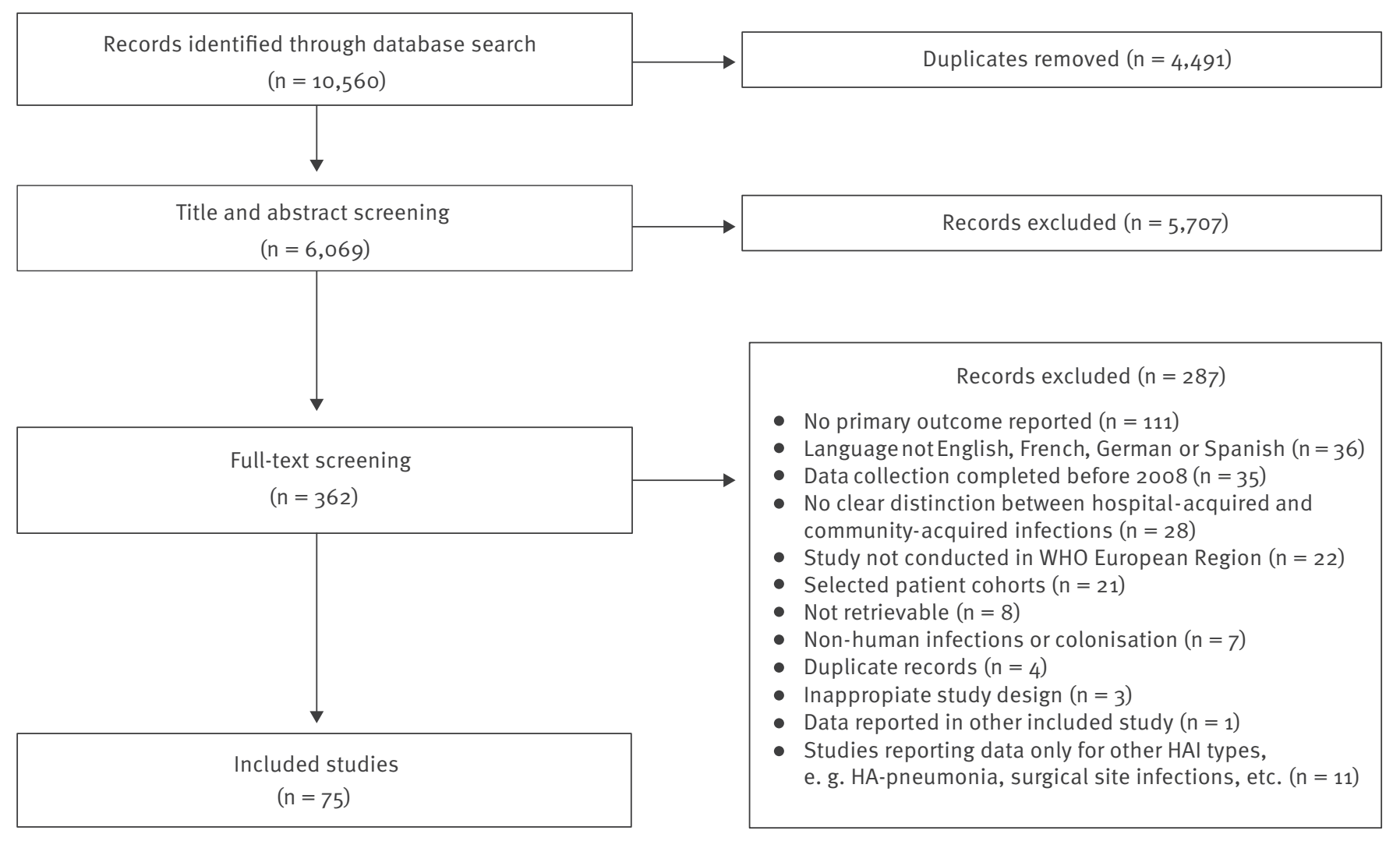

HA-pneumonia: hospital-acquired pneumonia; HAI: hospital-acquired infections; PRISMA: Preferred Reporting Items for Systematic Reviews and Meta-Analyses; WHO: World Health Organization.

independently performed by three authors (SB, OA, RM) using Covidence, a screening and data extraction tool recommended by the Cochrane Community [22]. All disagreements were discussed for consensus or resolved by a third reviewer.

The study selection criteria are presented in Box 1.

The data of all eligible studies were independently extracted by three authors (SB, OA and RM). All disagreements were resolved through discussion. The data extraction included the primary and secondary outcomes and the following study characteristics: authors, year of publication, study period, country, study design, setting (e.g. hospital, intensive care unit (ICU), etc.), age groups, patient inclusion criteria and the HAl infection type (i.e. total HAI and HA-BSI). We contacted study authors via email where details regarding outcomes and reporting were needed.

Risk of bias assessment and statistical analysis The risk of bias for individual studies was assessed by two authors (SB and RM) using the risk of bias tool developed by Hoy et al. [23]. For data analysis and presentation, studies were grouped into hospital-wide, ICU-based, neonatal ICU-based studies, and other hospital units/wards (e. g. internal medicine, surgical units, etc.) as well as by HAl types (i. e. total HAI and $\mathrm{HA}-\mathrm{BSI}$ ). All statistical analyses were performed using $R$ version 3.6.1 and the $R$ package meta version 4.9.7 (R Foundation, Vienna, Austria) [24]. Pooled estimates were calculated using random-effects models with a Tukey Double Arcsine transformation [25] of the raw proportions. The DerSimonian-Laird estimator was used to define $\tau^{2}$ (between-study variance). The $\mathrm{I}^{2}$ statistics quantified the statistical heterogeneity of the selected studies.

\section{Results}

In total, we identified 6,069 unique records. After title and abstract screening, 362 studies were assessed in full-text review and $75[6,7,26-98]$ met all inclusion criteria (Figure 1).

\section{Study characteristics}

The characteristics and individual study estimates are summarised in Supplementary Material, Table S1-S7. Among the 75 included studies, 28 [7,26-52] 
Summary of all primary outcomes on hospital-acquired infections caused by enterococci stratified by study setting, WHO European Region, 1 January 2010-4 February 2020

\begin{tabular}{|c|c|c|c|c|c|c|}
\hline Study setting & $\begin{array}{l}\text { Infection } \\
\text { type }\end{array}$ & Pathogen & Number of studies & $\begin{array}{l}\text { Pooled estimate } \\
\qquad(95 \% \mathrm{Cl})\end{array}$ & $\begin{array}{c}\text { Inter-study } \\
\text { heterogeneity } \\
\left(\left.\right|^{2} \text { statistics }\right)\end{array}$ & $\begin{array}{l}\text { Range of } \\
\text { individual } \\
\text { study } \\
\text { estimates }\end{array}$ \\
\hline \multicolumn{7}{|c|}{ Point prevalence (cases per 1,000 patients) } \\
\hline \multirow{4}{*}{$\begin{array}{l}\text { Hospital } \\
\text { patients }\end{array}$} & \multirow{2}{*}{ All HAl } & Enterococcus spp. $^{a}$ & $5[29,33,39,44,48]$ & $4.6(2.96-.7)$ & $48 \%$ & $2.0-12.5$ \\
\hline & & VRE & \multicolumn{4}{|c|}{ NA } \\
\hline & \multirow{2}{*}{ HA-BSI } & Enterococcus spp. $^{\mathrm{a}}$ & $3[29,44,48]$ & $0.63(0.00-2.1)$ & $27 \%$ & $0-2.5$ \\
\hline & & VRE & \multicolumn{4}{|c|}{ NA } \\
\hline \multirow{4}{*}{ ICU patients } & \multirow[t]{2}{*}{ All HAI } & Enterococcus spp. ${ }^{\mathrm{a}}$ & $1[81]$ & $\begin{array}{c}48.78 \\
(22.91-83.1)\end{array}$ & \multicolumn{2}{|c|}{ NA } \\
\hline & & VRE & & NA & & \\
\hline & \multirow{2}{*}{ HA-BSI } & Enterococcus spp ${ }^{\mathrm{a}}$ & $3[63,69,81]$ & $5.5(1.6-11.1)$ & $15 \%$ & $3.1-14.6$ \\
\hline & & VRE & $1[81]$ & $9.8(0.15-29.2)$ & \multicolumn{2}{|c|}{ NA } \\
\hline \multicolumn{7}{|c|}{ Incidence (new cases per 1,000 patients) } \\
\hline \multirow{4}{*}{$\begin{array}{l}\text { Hospital } \\
\text { patients }\end{array}$} & \multirow{2}{*}{ All HAI } & Enterococcus spp. $^{a}$ & $5[28,32,41,45,51]$ & $6.9(0.76-19.0)$ & $100 \%$ & $0.71-24.8$ \\
\hline & & VRE & $2[45,51]$ & $1.8(1.6-2.1)$ & $0 \%$ & $2.0-2.9$ \\
\hline & \multirow{2}{*}{ HA-BSI } & Enterococcus spp. ${ }^{a}$ & $6[7,30,37,41,46,54]$ & $0.62(0.34-0.99)$ & $97 \%$ & $0.18-1.1$ \\
\hline & & VRE & $1[7]$ & $0.37(0.31-0.43)$ & \multicolumn{2}{|c|}{ NA } \\
\hline \multirow{4}{*}{ ICU patients } & \multirow{2}{*}{ All HAl } & Enterococcus spp. ${ }^{a}$ & $\begin{array}{c}14[6,55,57,61,64,65,70,71,77,83,85- \\
87,102]\end{array}$ & $9.6(6.3-13.5)$ & $96 \%$ & $0.39-36.0$ \\
\hline & & VRE & $9[6,53,63,69,72,75,78,83,84]$ & $2.6(0.53-5.8)$ & $89 \%$ & $0-9.7$ \\
\hline & \multirow[t]{2}{*}{ HA-BSI } & Enterococcus spp. ${ }^{\mathrm{a}}$ & $\begin{array}{c}12 \\
{[62,71,73,75-77,79,83,84,86,87,102]}\end{array}$ & $6.1(1.9-12.3)$ & $97 \%$ & $0-24.7$ \\
\hline & & VRE & $8[62,73,75,76,80,84,87,102]$ & $0.06(0.00-2.10)$ & $79 \%$ & $0-9.9$ \\
\hline \multirow{4}{*}{ Neonatal ICU } & \multirow{2}{*}{ All HAI } & Enterococcus spp. $^{\mathrm{a}}$ & $5[89-93]$ & $2.0(0.05-5.7)$ & $71 \%$ & $0-15.9$ \\
\hline & & VRE & $4[89-92]$ & $0(0.00-0.32)$ & $0 \%$ & o \\
\hline & \multirow{2}{*}{ HA-BSI } & Enterococcus spp. ${ }^{a}$ & $6[46,88-90,92,94]$ & $2.3(0.95-4.1)$ & $61 \%$ & $0-5.1$ \\
\hline & & VRE & $4[89-92]$ & $0(0.00-0.32)$ & $0 \%$ & o \\
\hline \multicolumn{7}{|c|}{ Incidence density (cases per 1,000 patient days) } \\
\hline \multirow{4}{*}{$\begin{array}{l}\text { Hospital } \\
\text { patients }\end{array}$} & \multirow{2}{*}{ All HAl } & Enterococcus spp. ${ }^{a}$ & $3[28,41,43]$ & $0.34(0.08-0.78)$ & $93 \%$ & $0.14-0.92$ \\
\hline & & VRE & $1[43]$ & 0.02 & $\mathrm{~N} A$ & \\
\hline & $\mathrm{HA}-\mathrm{BSI}$ & Enterococcus spp. $^{\mathrm{a}}$ & $5[31,38,40,41,49,54]$ & $0.08(0.05-0.12)$ & $99 \%$ & $0.03-0.14$ \\
\hline & & VRE & $3[31,40,49]$ & $0.02(0.00-0.06)$ & $99 \%$ & $0-0.12$ \\
\hline & Аll HAI & Enterococcus spp. $^{a}$ & $9[6,55,64,70,71,77,85,87,102]$ & $0.92(0.41-1.60)$ & $93 \%$ & $0.05-2.57$ \\
\hline ICH patients & All HAl & VRE & $6[6,55,71,77,85,102]$ & $0.16(0.03-0.37)$ & $75 \%$ & $0-0.62$ \\
\hline tou pattemts & HASI & Enterococcus spp. $^{\text {a }}$ & $8[71,73,75,77,79,84,87,102]$ & $0.61(0.08-1.6)$ & $96 \%$ & $0-3.0$ \\
\hline & $A A-B S \mid$ & VRE & $5[73,75,84,87,102]$ & $0.01(0.00-0.12)$ & $70 \%$ & $0-0.76$ \\
\hline & All HAL & Enterococcus spp. $^{a}$ & 4 [89-92] & $0.15(0-0.54)$ & $84 \%$ & $0-1.5$ \\
\hline Nompotal $\mathrm{Cl}$ & All HAl & VRE & $4[89-92]$ & $0(0.00-0.01)$ & $0 \%$ & 0 \\
\hline Neonatalicu & HA RSI & Enterococcus spp. ${ }^{a}$ & $3[89,90,94]$ & $0.11(0.01-0.29)$ & $84 \%$ & $0.02-0.24$ \\
\hline & HA-BSI & VRE & $3[89-91]$ & $0(0.000 .01)$ & $0 \%$ & 0 \\
\hline All-cause mor & ality among & atients with enteroco & $\mathrm{Cal} \mathrm{HAI}$ & & & \\
\hline Hospital & $\mathrm{HACl}$ & Enterococcus spp. ${ }^{a}$ & $5[37,42,47,50,103]$ & $21.9(15.7-28.9)$ & $85 \%$ & $14.3-32.3$ \\
\hline patients & HA-BSI & VRE & $2[42,49]$ & $33.5(13.0-57.3)$ & $45 \%$ & $14.3-41.3$ \\
\hline IIU nationtc & АІнАн & Enterococcus spp. ${ }^{a}$ & $1[6]$ & $31.0 \%$ & $\mathrm{NA}$ & \\
\hline ICU patients & All HAl & VRE & $2[6,80]$ & $33.0(11.9-57.7)$ & $0 \%$ & $27.3-42.9$ \\
\hline Neonatal ICU & HA-BSI & Enterococcus spp. & 1 [94] & $0 \%$ & $\mathrm{NA}$ & \\
\hline
\end{tabular}

$\mathrm{Cl}$ : confidence interval; HAI: hospital-acquired infections; HA-BSI: hospital-acquired bloodstream infections; ICU: intensive care units; NA: not applicable; VRE: vancomycin-resistant Enterococcus spp.; WHO: World Health Organization.

a Including vancomycin-sensitive and resistant strains. 
were conducted hospital wide, $34[6,53-85]$ in ICU, nine [44,86-93] in neonatal ICU and five studies [9498] were performed in other settings, such as internal medicine and surgical units. The studies were distributed across the WHO European Region (Supplementary Material, Figure S1. Geographical distribution of the included studies across the WHO European Region); studies from Turkey $(n=20)$, Italy $(n=10)$ and Poland $(n=9)$ were overrepresented. In total, nine studies were point prevalence studies, while the remaining 66 studies were incidence studies.

The results specifically for $E$. faecium and VREF are not presented in the main text of this study but are instead described in the Supplementary Material.

\section{Risk of bias assessment}

The risk of bias for the representativeness of the studied hospital population was assessed as high in the majority of studies (69/75) (Supplementary Material, Table S8. Risk of bias assessment of included studies). Since these studies were single centre studies and/or included data from patients treated in academic medical centres, the representativeness of the included patients for the general hospital population in a given region or country was therefore unclear or low in these studies. Six studies [33,36,37,40,46,61] included nationally representative hospital populations. The risk of bias for the applied case definitions (i.e. hospital-acquired infections) was judged as low for most studies, since the majority of the studies (55/75) used HAI definitions based on the United States (US) Centers for Disease Control and Prevention criteria and the National Healthcare Safety Network criteria $[99,100]$. These validated definitions are widely used in the surveillance of HAI. More than half (46/75) of the studies did not report the used pathogen identification and/or antimicrobial susceptibility testing method and/or interpretation guideline (e.g. The European Committee on Antimicrobial Susceptibility Testing, Clinical and Laboratory Standards Institute). For this reason, the risk of bias with regards to the validity and reliability of the methodology used in these studies to identify enterococci and vancomycin-resistant strains was considered high (item 7, Supplementary Material, Table S8). In epidemiological surveys, HAI are typically defined as infections that occur $48 \mathrm{~h}$ after admission. That means that only patients with a hospital stay longer than $48 \mathrm{~h}$ in these studies are at risk of developing $\mathrm{HAl}$ and hence represent the appropriate denominator population for the parameters of interest (i.e. prevalence, incidence and mortality). Consequently, only studies including patients with a hospital stay longer than $48 \mathrm{~h}$ are judged as low risk of bias for item 10 (33/75 studies).

Prevalence and incidence of hospital-acquired infections caused by Enterococcus spp. and vancomycin-resistant Enterococcus spp.

Five point prevalence studies $[27,31,37,42,46]$ reported hospital-wide prevalence between 2.0 and 12.5 cases of Enterococcus spp. (including vancomycin-sensitive and -resistant strains) HAI per 1,000 hospital patients (pooled estimate: 4.6; 95\% confidence interval (CI): 2.9-6.7) (Table). Similarly, based on five incidence studies, the pooled hospital-wide incidence of Enterococcus spp. HAl was 6.9 (95\% Cl: 0.76-19.0; range: $0.71-24.8)$ cases per 1,000 hospital patients (Figure 2A; Table). Two hospital-wide incidence studies reported 2.9 and 2.0 cases per 1,000 patients for $\mathrm{HAl}$ caused by VRE. For HA-BSI caused by Enterococcus spp., the hospital incidence ranged between 0.18 and 1.1 cases per 1,000 patients (pooled estimate: 0.62; 95\% $\mathrm{Cl}$ : 0.34-0.99, six studies) (Table).

Fourteen studies reported $[6,53,55,59,62,63,68,6$ $9,72,75,81,82,84,85]$ data on the incidence of $\mathrm{HAl}$ caused by Enterococcus spp. in ICU. The individual study estimates ranged between 0.39 and 36.0 cases per 1,000 ICU patients (pooled estimate: 9.6; 95\% $\mathrm{Cl}$ : 6.3-13.5) (Figure 2B; Table). For HAl caused by VRE, the pooled estimate was 2.6 (95\% Cl: 0.5-5.8) cases per 1,000 ICU patients, with individual studies ranging from o to 9.7 cases per 1,000 patients. For HA-BSI, 12 studies reported ICU incidences between 0 and 24.7 Enterococcus spp. cases per 1,000 ICU patients (pooled estimate: 6.1; 95\% Cl: 1.9-12.3) (Table). Notably, two of eight studies identified cases of HA-BSI with VRE (range: 2.3-9.9). Data on the incidence and incidence density of HAI and HA-BSI caused by Enterococcus spp. in neonatal ICU are summarised in Table.

One study reported data on the population-based incidence or prevalence of enterococcal HAI. In this population-based study from Denmark [45], the incidence of monomicrobial enterococcal HA-BSI caused by Enterococcus spp. and VRE was 7.1 per 100,000 person-years and 0.1 per 100,000 person-years.

\section{Incidence density of hospital-acquired infections caused by Enterococcus spp. and} vancomycin-resistant Enterococcus spp.

As shown by three studies $[26,39,41]$, the hospital incidence density of HAl caused by Enterococcus spp. varied between 0.14 and 0.92 cases per 1,000 hospital patient days (pooled estimate: $0.34 ; 95 \% \mathrm{Cl}: 0.08-$ 0.78) (Table). The ICU incidence density of hospitalacquired Enterococcus spp. ranged between 0.05 and 2.6 cases per 1,000 ICU patient days (pooled estimate: 0.92; 95\% Cl: 0.41-1.6, nine studies) (Table). For HAI caused by VRE, the pooled ICU incidence density was 0.16 (95\% Cl: $0.03-0.37$ ), with an individual study range of o to 0.62 cases per 1,000 ICU patient days.

For HA-BSI caused by Enterococcus spp., five studies reported $[29,36,38,39,52]$ incidence densities between 0.03 and 0.14 cases per 1,000 hospital patient days (pooled estimate: 0.08; 95\% Cl: 0.05-0.12) (Table). In ICU, the pooled incidence density for Enterococcus spp. HA-BSI was $0.61(95 \% \mathrm{Cl}: 0.08-1.6)$ cases per 1,000 patient ICU days (eight studies, range: 0-3.0) (Table). 


\section{FIGURE 2}

Incidence of hospital-acquired infections caused by Enterococcus spp. and vancomycin-resistant Enterococcus spp., WHO European Region, 1 January 2010-4 February 2020

\section{A. Hospital-wide incidence of HAI caused by Enterococcus spp. and VRE}

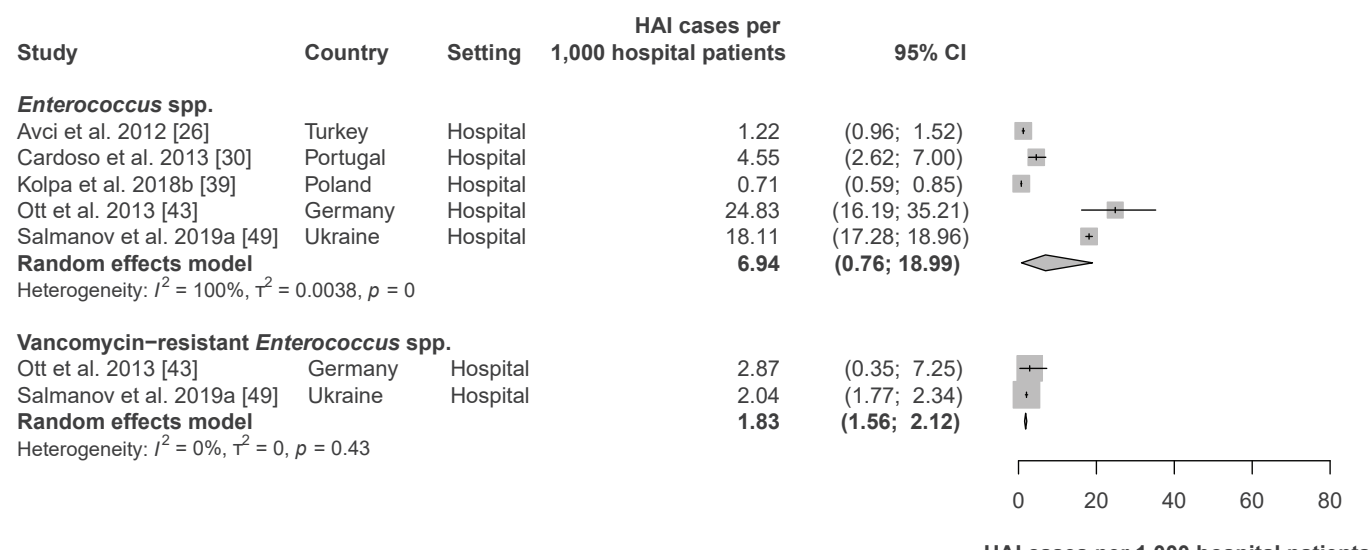

\section{B. Incidence of HAI caused by Enterococcus spp. and VRE in ICU}

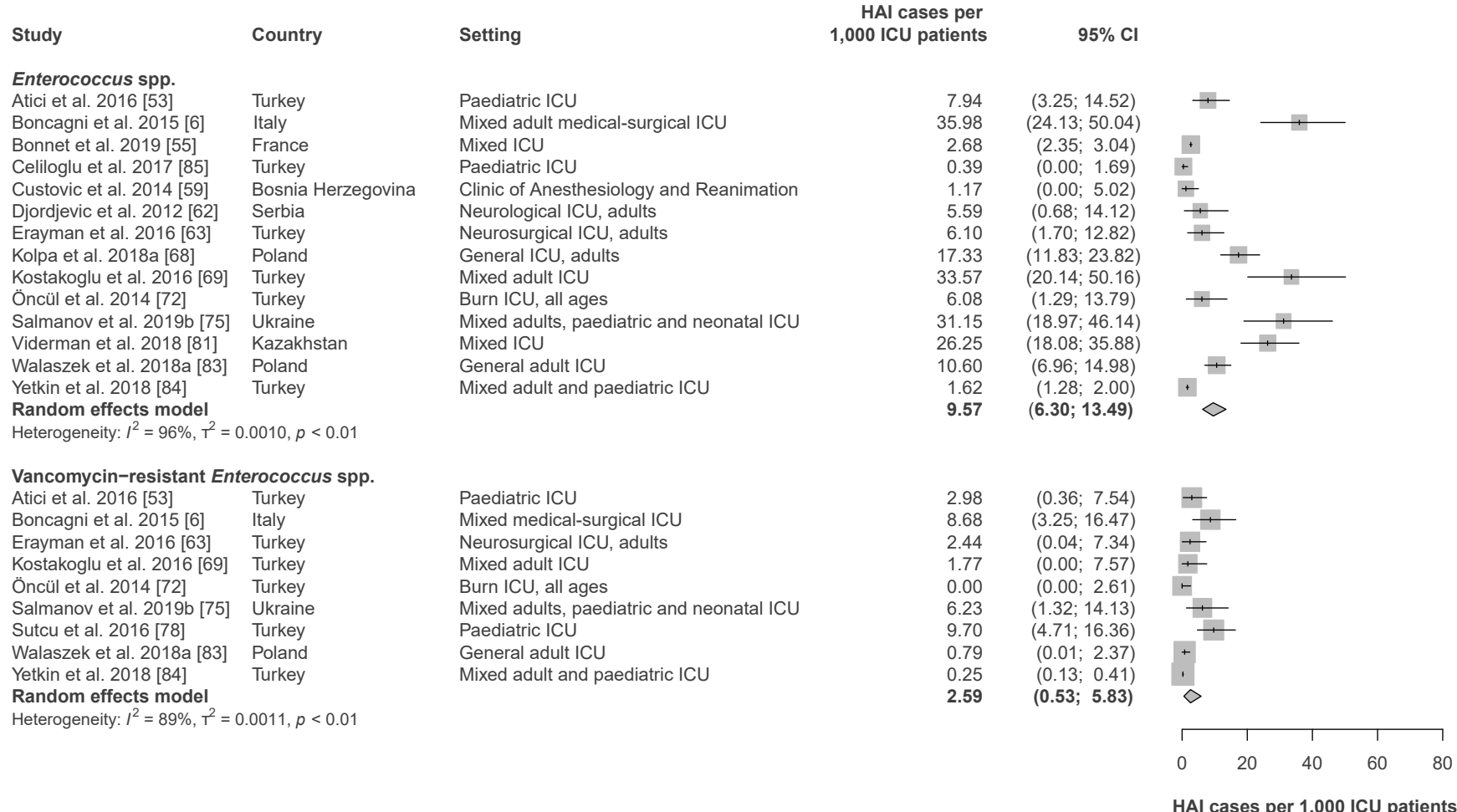

$\mathrm{Cl}$ : confidence interval; HAI: hospital-acquired infections; ICU: intensive care units; WHO: World Health Organization.

The incidence of HAl caused by Enterococcus spp. and vancomycin-resistant Enterococcus spp. as cases per 1,00o patients. Cases of HAl caused by Enterococcus spp. include vancomycin-resistant and -sensitive strains. Pooled estimates were calculated using random-effects models with a Tukey Double Arcsine transformation of the raw proportions. The DerSimonian-Laird estimator was used to define $\tau 2$ (between-study variance). 
All-cause mortality of patients with hospital-acquired bloodstream infections caused by Enterococcus spp. and vancomycinresistant Enterococcus spp., WHO European Region, 1 January 2010-4 February 2020

\begin{tabular}{|c|c|}
\hline Study & Country \\
\hline \multicolumn{2}{|l|}{ Enterococcus spp. } \\
\hline Green et al. 2015 [35] & United Kingdom \\
\hline Huttunen et al. $2015[38]$ & Finland \\
\hline Kontula et al. 2018 [40] & Finland \\
\hline Pinholt et al. 2014 [45] & Denmark \\
\hline Saliba et al. 2018 [48] & Spain \\
\hline \multicolumn{2}{|l|}{ Random effects model } \\
\hline \multicolumn{2}{|c|}{ Heterogeneity: $I^{2}=85 \%, T^{2}=0.0056, p<0.01$} \\
\hline \multicolumn{2}{|c|}{ Vancomycin-resistant Enterococcus spp. } \\
\hline Kontula et al. 2018 [40] & Finland \\
\hline Ryan et al. 2015 [47] & Ireland \\
\hline \multicolumn{2}{|l|}{ Random effects model } \\
\hline Heterogeneity: $I^{2}=$ & 147 \\
\hline
\end{tabular}

Setting
Hospital
Hospital
Hospital
Hospital
Hospital

Mortality (\%)

Hospital Hospital

\subsection{9}

\begin{tabular}{l}
14.29 \\
19.21 \\
20.41 \\
32.27 \\
20.00 \\
\hline 1.93
\end{tabular}

21.93

14.29

41.33

33.50
$95 \% \mathrm{Cl}$

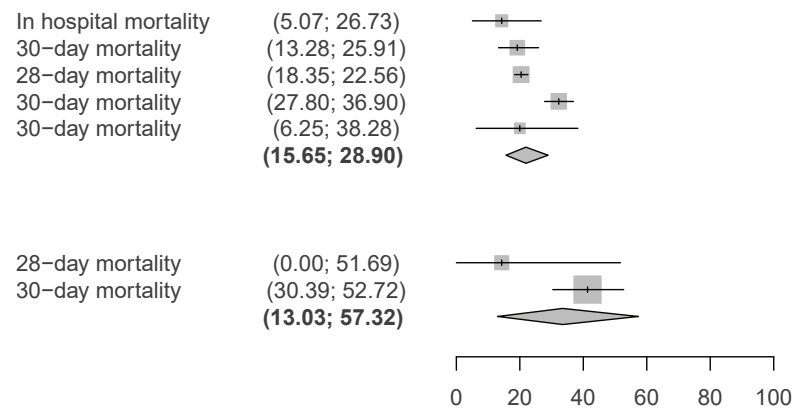

All-cause mortality of patients with HA-BSI (\%)

$\mathrm{Cl}$ : confidence interval; HA-BSI: hospital-acquired bloodstream infections; HAI: hospital-acquired infections; ICU: intensive care units; WHO: World Health Organization.

Pooled all-cause mortality (\%) of patients with HA-BSI caused by Enterococcus spp. and vancomycin-resistant Enterococcus spp. Cases of HAI caused by Enterococcus spp. include vancomycin-resistant and -sensitive strains. Pooled estimates were calculated using randomeffects models with a Tukey Double Arcsine transformation of the raw proportions. The DerSimonian-Laird estimator was used to define $\tau^{2}$ (between-study variance).

\section{Mortality}

The all-cause mortality recorded among patients with HA-BSI caused by Enterococcus spp. ranged between $14.3 \%$ and $32.3 \%$ (pooled estimate: $21.9 \%$; $95 \% \mathrm{Cl}$ : 15.7-28.9, five studies) (Figure 3; Table). Based on two studies $[40,47]$, the pooled all-cause mortality of patients with HA-BSI caused by VRE was 33.5\% (95\% $\mathrm{Cl}$ : 13.0-57.3; range: 19.1-41.3). Importantly, Brady et al. 2017 [7] provided data on the attributable mortality of HA-BSI with enterococci. For Enterococcus spp. (including vancomycin-susceptible and -resistant strains) and VRE, this study reported an attributable mortality of $17.7 \%$ and $19.1 \%$, respectively. This study also showed that the mortality of patients with HA-BSs caused by vancomycin-resistant Enterococcus spp. (19.1\%) was similar to the mortality of HA-BSI patients with vancomycin-sensitive Enterococcus spp. (17.0\%).

\section{Proportion of Enterococcus spp. and vancomycin-resistant Enterococcus spp. among all pathogens isolated from patient with HAI} As reported by 11 hospital-wide studies, the proportion of Enterococcus spp. among all microorganisms isolated from $\mathrm{HAl}$ patients ranged between $6.1 \%$ and 17.5\% (pooled estimate: 10.9\%; 95\% Cl: 8.7-13.4) (Figure 4A; Supplementary Material, Table S6). Based on three studies $[41,49,101]$, VRE isolates accounted for $0.39 \%$ to $2.0 \%$ (pooled estimate: $1.1 \%$; $95 \% \mathrm{Cl}$ : $0.21-$ 2.7) of all HAl pathogens.
Compared with hospital-wide estimates, substantially lower Enterococcus spp. proportions were observed in $\mathrm{HAl}$ isolates from patients treated in ICU. Only $3.8 \%$ (95\% Cl: 2.9-4.8) of all isolated $\mathrm{HAl}$ microorganisms were identified as Enterococcus spp. (range: 0.737.6, 17 studies,) (Figure 4B; Supplementary Material, Table S6) in ICU. As reported by nine ICU studies $[6,8,53,63,65,72,75,82,84]$, the proportion of VRE ranged between $0 \%$ and $1.8 \%$ (pooled estimate: $0.55 \%$; $95 \% \mathrm{Cl}: 0.20-1.0)$.

In HA-BSI at the hospital level, the proportion of Enterococcus spp. among HA-BSI isolates ranged between $0 \%$ and $19.6 \%$ (pooled estimate: 9.2\%; 95\% $\mathrm{Cl}: 6.9-11.7,17$ studies), while the proportion of VRE varied between 0\% and 1.9\% (Supplementary Material, Table S6). Compared with the hospital-wide estimates, similar proportions of Enterococcus spp. in HA-BSI isolates were observed in ICU (pooled estimate: 9.2\%; 95\% Cl: 6.7-11.8; range: 0-28.6, 21 studies) (Supplementary Material, Table S6). In ICU, the proportion of VRE among all isolates from HA-BSI patients varied between $0 \%$ and $10.1 \%$ (pooled estimate: $1.3 \%$; $95 \% \mathrm{Cl}: 0.16-3.2,11$ studies). In four of 11 studies, no VRE were found in isolates from ICU patients with HA-BSI. 


\section{FIGURE 4}

Proportion of Enterococcus spp. and vancomycin-resistant Enterococcus spp. among all microorganisms isolated from patients with hospital-acquired infections, WHO European Region, 1 January 2010-4 February 2020

\section{A. Proportion of Enterococcus spp. and VRE among all patients}

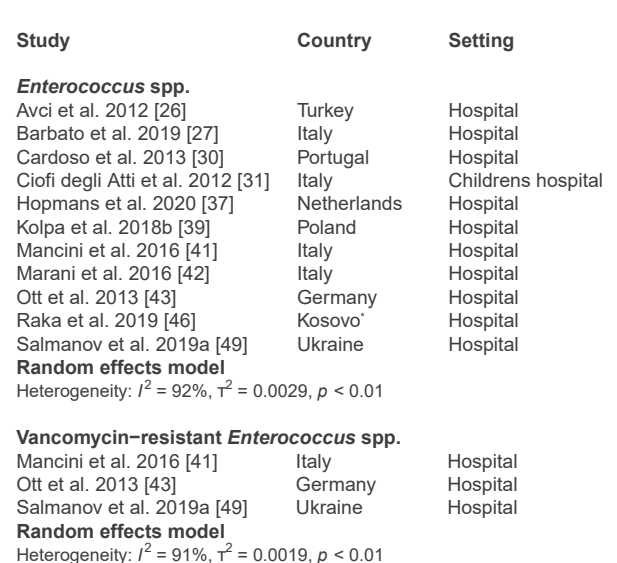

Proportion among all HAl microorganisms (\%) $\quad 95 \% \mathrm{Cl}$

Heterogeneity: $I^{2}=91 \%, T^{2}=0.0019, p<0.01$

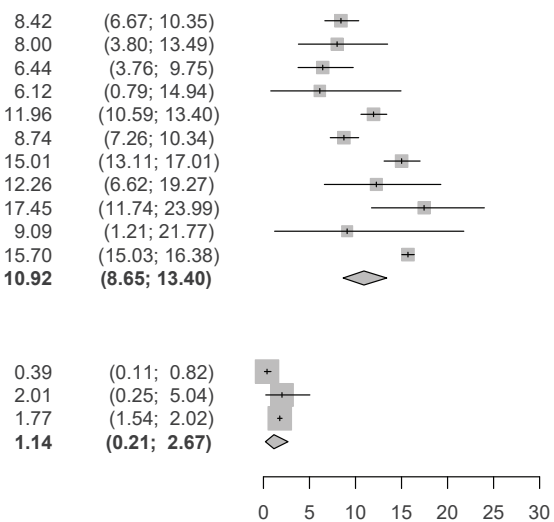

Proportion among all HAI microorganisms (\%)

\section{B. Proportion of Enterococcus spp. and VRE among ICU patients}

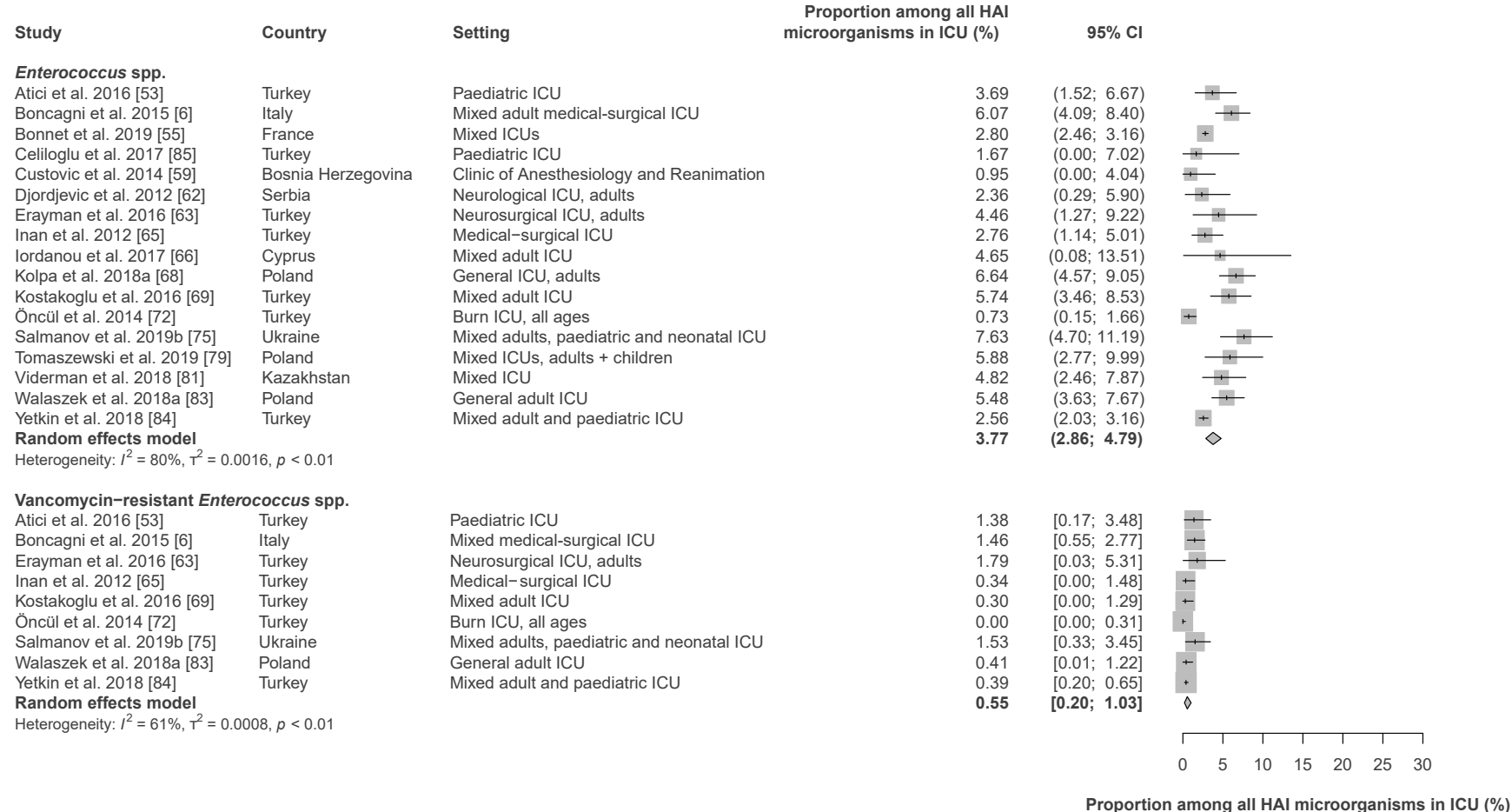

$\mathrm{Cl}$ : confidence interval; HAI: hospital-acquired infections; ICU: intensive care units; WHO: World Health Organization.

Cases of HAl caused by Enterococcus spp. include vancomycin-resistant and -sensitive strains. Pooled estimates were calculated using random-effects models with a Tukey Double Arcsine transformation of the raw proportions. The DerSimonian-Laird estimator was used to define 22 (between-study variance). 
Proportion of vancomycin resistance among Enterococcus spp. isolates from patients with hospital-acquired infections

Thirteen studies $[6,41,43,49,53,63,65,69,72,75,80,82$ ,84] provided data on vancomycin resistance proportion among all Enterococcus spp. isolates from patients with HAI in hospitals and ICUs. The VRE proportions ranged between $0 \%$ and 40\% (pooled hospital-wide estimate: $7.3 \%$; $95 \% \mathrm{Cl}$ : 1.5-16.3; pooled ICU estimate: 11.5\%; 95\% Cl: 4.7-20.1) (Figure 5A; Supplementary Material, Table S7).

In HA-BSI, a pooled vancomycin-resistant proportion of $3.0 \%(95 \% \mathrm{Cl}: 0-9.2)$ was observed hospital wide (Figure 5B; Supplementary Material, Table S7). Notably, while seven studies reported relatively low VRE proportions in HA-BSI (o-8.9\%), two studies from Ireland [7] and Poland [33] reported high proportions of $33 \%$. With the exception of three studies that found no vancomycin resistance, higher VRE proportions (range: 9.5-66.7, six studies) were found in HA-BSI Enterococcus spp. isolates from patients treated in ICU (Figure 5B; Supplementary Material, Table S7).

\section{Discussion}

In view of limited treatment options, HAI with Enterococcus spp. are a serious health issue in the WHO European Region, particularly in light of increasing vancomycin resistance. This study is, to the best of our knowledge, the first systematic review to provide a comprehensive summary of data on the epidemiology of hospital-acquired infections caused by Enterococcus spp. and VRE in Europe.

The identified studies reported a hospital-wide point prevalence of HAl caused by Enterococcus spp. between 3.3 and 12.5 cases per 1,000 hospital patients, which is similar to Australia (8.0 cases per 1,000 patients) [102] and Latin America (4.0 cases per 1,000 patients) [103]. In contrast, lower prevalences of Enterococcus spp. HAI were observed in the US [104] and China [105], 1.9 and 1.3 cases per 1,000 hospital patients, respectively, which might be explained by generally lower hospital point prevalence of HAI in the US 3.2\% [106] and in China 3.1\% [107] compared with Europe 5.5\% [4]. Another explanation might be broader screening practices and the implementation of contact precaution measures within the US healthcare system, particularly to control meticillin-resistant Staphylococcus aureus (MRSA) and VRE [108].

Our study emphasises the importance of Enterococcus spp. as a nosocomial pathogen, since it accounts for $6.1 \%$ to $17.5 \%$ of all pathogens isolated from patients with HAI. Enterococcus spp. usually remains among the top five most frequent nosocomial pathogens in Europe, despite the variation in species distribution across hospitals and regions [101,109-111]. In comparison, Enterococcus spp. is less frequently found in isolates from patients with HAI in the US [104] and China [105], 5\% and 3.1\% of all HAI pathogens, respectively. Our data show that VRE was found in $1.1 \%$ (range: $0.4-2.0$ ) of all pathogens isolated from HAl patients, which is lower than the mean proportion of MRSA (ca 5\%) observed in Europe [112]. However, in Germany [101] and Greece [109] VRE and MRSA are equally often found in HAI patients and in studies from Italy [110] and Ukraine [49], VRE is even more frequently isolated than MRSA, underlining the local heterogeneous distribution of nosocomial antibiotic-resistant pathogens. Interestingly, we found that Enterococcus spp. is less frequently isolated from HAI patients in ICU compared with patients treated hospital wide (10.9\% vs $3.8 \%$ ). However, the reasons for this observation are unclear.

Our study shows that the pooled vancomycin resistance proportions among HAl Enterococcus spp. were $7.3 \%$ hospital wide and $11.5 \%$ in isolates from patients in ICU, although individual study estimates varied somewhat. These pooled estimates are similar to the European Centre for Disease Prevention and Control data from the European Point Prevalence Survey $[113,114]$. In comparison to these European data, vancomycin resistance proportions are substantially lower in China $[115,116]$ and Japan [117], where VRE proportions lower than $2 \%$ were observed. Interestingly, other countries in eastern Asia observed much higher VRE proportions, such as in South Korea (33.4\%) [118] and Taiwan (40\%) [119]. Compared with the European estimates, VRE proportions in the US are also generally higher $(>20 \%)[120,121]$, which might be explained by the widespread use of vancomycin in US hospitals, which increased by more than 30\% between 2006 and 2012 [122].

For patients with HA-BSI caused by Enterococcus spp., all-cause mortality estimates ranged between $14.3 \%$ and $32.3 \%$ (pooled estimate: $21.1 \%$ ). These are higher $[35,38,40]$ or similar $[7,48]$ to the all-cause mortality rates observed for $S$. aureus and generally higher than those reported for $E$. coli $[7,35,38,40]$, which are other frequently encountered nosocomial pathogens. Substantial attention is paid to infection prevention and control (IPC) measures to address VRE, but our results show that enterococcal HAI as a whole are associated with a high incidence and mortality in Europe and should therefore receive more attention in IPC strategies.

An important observation of our study is that there is a large variation between individual study estimates of incidences/prevalences of $\mathrm{HAl}$ caused by Enterococcus spp. as well as for VRE proportions. This finding is similar to other systematic reviews around the world that also found large inter-study variations in the frequency of HAI [123-125]. Some of this heterogeneity might be explained by different methodological approaches, including different inclusion/exclusion criteria and microbiological sampling routines. In many published studies, data on the causative pathogen are not available for a substantial proportion of HAI 
episodes ( $>40 \%$ ) because of the lack of microbiological samples taken or incomplete data. This would ultimately lead to a substantial underestimation of the frequency of HAl caused by Enterococcus spp. To avoid this source of bias, we only included studies where pathogen identification results were reported for almost all $\mathrm{HAI}$ episodes. In addition to methodological differences, the large variation between individual study estimates also reflects true differences in the occurrence of nosocomial pathogens, including Enterococcus spp., between countries, regions and individual hospitals. For example, in a large multicentre study from Ukraine [49], Escherichia coli, Staphylococcus aureus and Enterococcus spp. were the predominant pathogens isolated from patients with HAI, while in a multicentre study from Greece, Klebsiella spp., Pseud omonas aeruginosa and Acinetobacter spp. were the most frequently identified nosocomial pathogens [126]. Furthermore, there is great variation in IPC policies and resources across Europe [127], which also explains the observed variations of HAl caused by Enterococcus spp. and VRE.

Since vancomycin resistance is predominantly found in $E$. faecium and less in $E$. faecalis and/or other enterococci species $[7,18,75,118]$, vancomycin resistance proportions in Enterococcus spp. HAI isolates are also largely influenced by the proportion of $E$. faecium among all Enterococcus spp. isolates. Moreover, vancomycin resistance proportions in E. faecium differ across countries [18] and even within countries [17], which also explains the observed variation in VRE proportion described in our study. Moreover, nosocomial outbreaks and local spread of E. faecium genotypes associated with vancomycin resistance especially VanA and VanB in Europe [128] and increased virulence such as the esp and hyl genes can result in a higher VRE incidence in certain regions and hospitals. Another explanation for the observed inter-study variations in HAl caused by VRE are the profound differences in the consumption of glycopeptides/vancomycin, fluoroquinolones and third generation cephalosporins in Europe $[129,130]$, whose usage is associated with VRE infections and colonisations in hospitals [131-135].

This systematic review is a comprehensive summary of recent data on the epidemiology of Enterococcus spp. and VRE in the WHO European Region, including 75 studies with data on over 8.5 million hospitalised patients with $154,000 \mathrm{HAl}$ episodes. The majority of studies were based on routine HAI surveillance systems, including data from unselected patient cohorts. However, because of language restrictions in the literature selection, potentially relevant studies might have been excluded, for example from eastern European countries. Also, the majority of the included studies were conducted in academic medical centres and/ or tertiary care hospitals and the representativeness of hospitalised patients and external validity of the study results might therefore be limited. Despite unclear representativeness of most studies, the overall quality of the studies and thus the quality of evidence was moderate to high. Another limitation is that many studies did not report vancomycin resistance profiles of Enterococcus spp. and data on the epidemiology of VRE are therefore limited. Importantly, since enterococci frequently colonise healthy people and are often detected in mixed infections, they may not be the causative microorganism in all HAl reported by the included studies. Especially in intra-abdominal, pelvic and soft tissue infections, the clinical relevance of Enterococcus spp. is debated [136]. Although the included studies were conducted in 21 different countries in the WHO European Region, the studies were not evenly distributed across Europe, which might lead to a geographical bias. For example, ICU-based studies were predominantly from studies in eastern and southern Europe and none was conducted in Scandinavia. Notably, studies from Turkey were overrepresented within the study set reporting VRE data. However, Turkish data did not systematically differ to data from other European countries. More nationally representative studies with complete microbiological and antimicrobial resistance profiles, including populations-based data, are needed in order to fully understand the epidemiology of HAl caused by Enterococcus spp. and VRE. In most analyses, a large statistical heterogeneity was observed $\left(1^{2}>80 \%\right)$ and the pooled estimates should be interpreted with caution. We therefore also provided the range of individual study estimates for all outcomes.

\section{Conclusions}

Our data show that HAl caused by Enterococcus spp. and VRE are frequently identified among hospital patients and associated with high mortality in the WHO European Region. Continuous monitoring and the improved implementation of infection prevention and control programs as well as antibiotic stewardship measures are essential to reduce the burden of HAI caused by enterococci.

\section{${ }^{*}$ Note}

This designation is without prejudice to positions on status, and is in line with UNSCR $1244 / 99$ and the ICJ Opinion on the Kosovo declaration of independence.

\section{Acknowledgements}

We thank our colleague Angelina Taylor at the Robert Koch Institute (RKI) for her contribution (proofreading and editing assistance) to this study.

Funding: This work was supported by internal funding of the RKI.

Conflict of Interest

None declared. 


\section{Authors' contributions}

$\mathrm{SB}$, TE and RM designed the study. SB, OA and performed literature screening, study selection and data extraction. SB and RM assessed the risk of bias. RM conducted the statistical analyses. SB and RM led the writing of the manuscript. All authors revised the manuscript for important intellectual content.

\section{References}

1. Fisher K, Phillips C. The ecology, epidemiology and virulence of Enterococcus. Microbiology (Reading). 2009;155(Pt 6):1749-57. https://doi.org/10.1099/mic.0.026385-0 PMID: 19383684

2. Arias CA, Murray BE. The rise of the Enterococcus: beyond vancomycin resistance. Nat Rev Microbiol. 2012;10(4):266-78. https://doi.org/10.1038/nrmicr02761 PMID: 22421879

3. Weiner LM, Webb AK, Limbago B, Dudeck MA, Patel J, Kallen AJ, et al. Antimicrobial-resistant pathogens associated with healthcare-associated infections: summary of data reported to the national healthcare safety network at the centers for disease control and prevention, 2011-2014. Infect Control Hosp Epidemiol. 2016;37(11):1288-301. https://doi.org/10.1017/ ice.2016.174 PMID: 27573805

4. Suetens C, Latour K, Kärki T, Ricchizzi E, Kinross P, Moro ML, et al. Prevalence of healthcare-associated infections, estimated incidence and composite antimicrobial resistance index in acute care hospitals and long-term care facilities: results from two European point prevalence surveys, 2016 to 2017. Euro Surveill. 2018;23(46):1800516. https://doi.org/10.2807/15607917.ES.2018.23.46.1800516 PMID: 30458912

5. Pinholt M, Ostergaard C, Arpi M, Bruun NE, Schønheyder HC, Gradel KO, et al. Incidence, clinical characteristics and 30-day mortality of enterococcal bacteraemia in Denmark 20062009: a population-based cohort study. Clin Microbiol Infect. 2014;20(2):145-51. https://doi.org/10.1111/1469-0691.12236 PMID: 23647880

6. Boncagni F, Francolini R, Nataloni S, Skrami E, Gesuita $R$, Donati A, et al. Epidemiology and clinical outcome of Healthcare-Associated Infections: a 4-year experience of an Italian ICU. Minerva Anestesiol. 2015;81(7):765-75. PMID: 25582669

7. Brady M, Oza A, Cunney R, Burns K. Attributable mortality of hospital-acquired bloodstream infections in Ireland. J Hosp Infect. 2017;96(1):35-41. https://doi.org/10.1016/j. jhin.2017.02.006 PMID: 28359546

8. Caballero-Granado FJ, Becerril B, Cuberos L, Bernabeu M, Cisneros JM, Pachón J. Attributable mortality rate and duration of hospital stay associated with enterococcal bacteremia. Clin Infect Dis. 2001;32(4):587-94. https://doi.org/10.1086/318717 PMID: 11181122

9. Kramer TS, Remschmidt C, Werner S, Behnke M, Schwab F, Werner $G$, et al. The importance of adjusting for enterococcus species when assessing the burden of vancomycin resistance: a cohort study including over 1000 cases of enterococcal bloodstream infections. Antimicrob Resist Infect Control. 2018;7(1):133. https://doi.org/10.1186/s13756-018-0419-9 PMID: 30459945

10. Puchter L, Chaberny IF, Schwab F, Vonberg RP, Bange FC, Ebadi E. Economic burden of nosocomial infections caused by vancomycin-resistant enterococci. Antimicrob Resist Infect Control. 2018;7(1):1. https://doi.org/10.1186/s13756-0170291-z PMID: 29312658

11. O'Driscoll T, Crank CW. Vancomycin-resistant enterococcal infections: epidemiology, clinical manifestations, and optimal management. Infect Drug Resist. 2015;8:217-30. https://doi. org/10.2147/IDR.S54125 PMID: 26244026

12. Hollenbeck BL, Rice LB. Intrinsic and acquired resistance mechanisms in enterococcus. Virulence. 2012;3(5):421-33. https://doi.org/10.4161/viru.21282 PMID: 23076243

13. Raza T, Ullah SR, Mehmood K, Andleeb S. Vancomycin resistant Enterococci: A brief review. J Pak Med Assoc. 2018;68(5):76872. PMID: 29885179

14. Levine DP. Vancomycin: a history. Clin Infect Dis. 2006;42Suppl 1;S5-12. https://doi.org/10.1086/491709 PMID: 16323120

15. Uttley AH, Collins CH, Naidoo J, George RC. Vancomycinresistant enterococci. Lancet. 1988;1(8575-6):57-8. https://doi. org/10.1016/S0140-6736(88)91037-9 PMID: 2891921

16. Boyce JM. Vancomycin-resistant enterococcus. Detection, epidemiology, and control measures. Infect Dis Clin North Am. 1997;11(2):367-84. https://doi.org/10.1016/So8915520(05)70361-5 PMID: 9187952
17. Markwart R, Willrich N, Haller S, Noll I, Koppe U, Werner G, et al. The rise in vancomycin-resistant Enterococcus faecium in Germany: data from the German Antimicrobial Resistance Surveillance (ARS). Antimicrob Resist Infect Control. 2019;8(1):147. https://doi.org/10.1186/s13756-019-0594-3 PMID: 31485325

18. Ayobami O, Willrich N, Reuss A, Eckmanns T, Markwart $R$. The ongoing challenge of vancomycin-resistant Enterococcus faecium and Enterococcus faecalis in Europe: an epidemiological analysis of bloodstream infections. Emerg Microbes Infect. 2020;9(1):1180-93. https://doi.org/10.1080/2 2221751.2020.1769500 PMID: 32498615

19. Cassini A, Högberg LD, Plachouras D, Quattrocchi A, Hoxha A, Simonsen GS, et al. Attributable deaths and disabilityadjusted life-years caused by infections with antibioticresistant bacteria in the EU and the European Economic Area in 2015: a population-level modelling analysis. Lancet Infect Dis. 2019;19(1):56-66. https://doi.org/10.1016/S14733099(18)30605-4 PMID: 30409683

20. Schreiber PW, Sax H, Wolfensberger A, Clack L, Kuster $\mathrm{SP}$, Swissnoso. The preventable proportion of healthcareassociated infections 2005-2016: Systematic review and metaanalysis. Infect Control Hosp Epidemiol. 2018;39(11):1277-95. https://doi.org/10.1017/ice.2018.183 PMID: 30234463

21. Moher D, Liberati A, Tetzlaff J, Altman DG, PRISMA Group. Preferred reporting items for systematic reviews and meta-analyses: the PRISMA statement. PLoS Med. 2009;6(7):e1000097. https://doi.org/10.1371/journal. pmed.1000097 PMID: 19621072

22. Cochrane Community. Covidence. London: Cochrane. [Accessed: 26 Oct 2021]. Available from: https://community. cochrane.org/help/tools-and-software/covidence

23. Hoy D, Brooks P, Woolf A, Blyth F, March L, Bain C, et al. Assessing risk of bias in prevalence studies: modification of an existing tool and evidence of interrater agreement. Clin Epidemiol. 2012;65(9):934-9. https://doi.org/10.1016/j. jclinepi.2011.11.014 PMID: 22742910

24. Schwarzer G. meta: an R package for meta-analysis. R News. 2007;7(3):40-5

25. Barendregt JJ, Doi SA, Lee YY, Norman RE, Vos T. Meta-analysis of prevalence. J Epidemiol Community Health. 2013;67(11):9748. https://doi.org/10.1136/jech-2013-203104 PMID: 23963506

26. Avci M, Ozgenc O, Coskuner SA, Olut Al. Hospital acquired infections (HAI) in the elderly: comparison with the younger patients. Arch Gerontol Geriatr. 2012;54(1):247-50. https://doi. org/10.1016/j.archger.2011.03.014 PMID: 21529974

27. Barbato D, Castellani F, Angelozzi A, Isonne C, Baccolini V, Migliara G, et al. Prevalence survey of healthcare-associated infections in a large teaching hospital. Ann Ig. 2019;31(5):423 35. https://doi.org/10.7416/ai.2019.2304 PMID: 31304523

28. Blackburn RM, Henderson KL, Minaji M, Muller-Pebody B, Johnson AP, Sharland M. Exploring the epidemiology of hospital-acquired bloodstream infections in children in England (January 2009-March 2010) by linkage of national hospital admissions and microbiological databases. J Pediatric Infect Dis Soc. 2012;1(4):284-92. https://doi.org/10.1093/ jpids/piso84 PMID: 26619421

29. Blot K, Hammami N, Blot S, Vogelaers D, Lambert M-L. Increasing burden of Escherichia coli, Klebsiella pneumoniae, and Enterococcus faecium in hospital-acquired bloodstream infections (2000-2014): A national dynamic cohort study. Infect Control Hosp Epidemiol. 2019;40(6):705-9. https://doi. org/10.1017/ice.2019.59 PMID: 31012402

30. Cardoso T, Ribeiro O, Aragão I, Costa-Pereira A, Sarmento A. Differences in microbiological profile between communityacquired, healthcare-associated and hospital-acquired infections. Acta Med Port. 2013;26(4):377-84. PMID: 24016647

31. Ciofi Degli Atti ML, Cuttini M, Ravà L, Ceradini J, Paolini V, Ciliento G, et al. Trend of healthcare-associated infections in children: annual prevalence surveys in a research hospital in Italy, 2007-2010. J Hosp Infect. 2012;80(1):6-12. PMID: 22133896

32. De Angelis G, Fiori B, Menchinelli G, D’Inzeo T, Liotti FM, Morandotti GA, et al. Incidence and antimicrobial resistance trends in bloodstream infections caused by ESKAPE and Escherichia coli at a large teaching hospital in Rome, a 9-year analysis (2007-2015). Eur J Clin Microbiol Infect Dis 2018;37(9):1627-36. https://doi.org/10.1007/s10096-0183292-9 PMID: 29948360

33. Deptuła A, Trejnowska E, Dubiel G, Wanke-Rytt M, Deptuła M, Hryniewicz W. Healthcare associated bloodstream infections in Polish hospitals: prevalence, epidemiology and microbiology-summary data from the ECDC Point Prevalence Survey of Healthcare Associated Infections 2012-2015. Eur J Clin Microbiol Infect Dis. 2018;37(3):565-70. https://doi. org/10.1007/s10096-017-3150-1 PMID: 29189981 
34. Erdem D, Akan B, Kanyilmaz D, Demirelli G, Esingen S, Ornek $\mathrm{D}$, et al. The association between total parenteral nutrition and central line-associated bloodstream infection. Acta Med Mediter. 2015;31:1163-7.

35. Green N, Johnson AP, Henderson KL, Muller-Pebody B, Thelwall S, Robotham JV, et al. Quantifying the burden of hospitalacquired bloodstream infection in children in England by estimating excess length of hospital stay and mortality using a multistate analysis of linked, routinely collected data. J Pediatric Infect Dis Soc. 2015;4(4):305-12. https://doi. org/10.1093/jpids/piu073 PMID: 26582869

36. Gubbels S, Nielsen J, Voldstedlund M, Kristensen B, Schønheyder HC, Ellermann-Eriksen S, et al. National automated surveillance of hospital-acquired bacteremia in Denmark using a computer algorithm. Infect Control Hosp Epidemiol. 2017;38(5):559-66. https://doi.org/10.1017/ ice.2017.1 PMID: 28274300

37. Hopmans TEM, Smid EA, Wille JC, van der Kooi TII, Koek MBG, Vos MC, et al. Trends in prevalence of healthcareassociated infections and antimicrobial use in hospitals in the Netherlands: 10 years of national point-prevalence surveys. J Hosp Infect. 2020;104(2):181-7. https://doi.org/10.1016/j. jhin.2019.10.005 PMID: 31626863

38. Huttunen R, Åttman E, Aittoniemi J, Outinen T, Syrjänen J, Kärki $\mathrm{T}$, et al. Nosocomial bloodstream infections in a Finnish tertiary care hospital: a retrospective cohort study of 2175 episodes during the years 1999-2001 and 2005-2010. Infect Dis (Lond). 2015;47(1):20-6. https://doi.org/10.3109/00365548.2014.9567 91 PMID: 25351869

39. Kołpa M, Wałaszek M, Różańska A, Wolak Z, WójkowskaMach J. Hospital-wide surveillance of healthcare-associated infections as a source of information about specific hospital needs. A 5-year observation in a multiprofile provincial hospital in the south of Poland. Int J Environ Res Public Health. 2018;15(9):1956. https://doi.org/10.3390/ijerph15091956 PMID: 30205510

40. Kontula KSK, Skogberg K, Ollgren J, Järvinen A, Lyytikäinen 0 . The outcome and timing of death of 17,767 nosocomial bloodstream infections in acute care hospitals in Finland during 1999-2014. Eur J Clin Microbiol Infect Dis. 2018;37(5):945-52. https://doi.org/10.1007/s10096-018-3211-0 PMID: 29455272

41. Mancini A, Verdini D, La Vigna G, Recanatini C, Lombardi FE, Barocci S. Retrospective analysis of nosocomial infections in an Italian tertiary care hospital. New Microbiol. 2016;39(3):197205. PMID: 27284985

42. Marani A, Napoli C, Berdini S, Montesano M, Ferretti F, Di Ninno F, et al. Point prevalence surveys on healthcare acquired infections in medical and surgical wards of a teaching hospital in Rome. Ann Ig. 2016;28(4):274-81. https://doi.org/10.7416/ ai.2016.2106 PMID: 27479763

43. Ott E, Saathoff S, Graf K, Schwab F, Chaberny IF. The prevalence of nosocomial and community acquired infections in a university hospital: an observational study. Dtsch Arztebl Int. 2013;110(31-32):533-40. https://doi.org/10.3238/ arztebl.2013.0533 PMID: 24069074

44. Pérerz Lopéz A, Ladhani SN, Breathnach A, Planche T, Heath PT, Sharland M. Trends in paediatric nosocomial bacteraemia in a London tertiary hospital. Acta Paediatr. 2013;102(10):10059. https://doi.org/10.1111/apa.12347 PMID: 23837813

45. Pinholt M, Østergaard C, Arpi M, Bruun NE, Schønheyder HC, Gradel $\mathrm{KO}$, et al. Incidence, clinical characteristics and 30-day mortality of enterococcal bacteraemia in Denmark 2006 2009: a population-based cohort study. Clin Microbiol Infect. 2014;20(2):145-51. https://doi.org/10.1111/1469-0691.12236 PMID: 23647880

46. Raka L, Spahija G, Gashi-Gecaj A, Hamza A, Haxhiu E, Rashiti $A$, et al. Point prevalence survey of healthcare-associated infections and antimicrobial use in Kosovo hospitals. Infect Dis Rep. 2019;11(1):7975. https://doi.org/10.4081/idr.2019.7975 PMID: 30996847

47. Ryan L, O'Mahony E, Wrenn C, FitzGerald S, Fox U, Boyle B, et al. Epidemiology and molecular typing of VRE bloodstream isolates in an Irish tertiary care hospital. J Antimicrob Chemother. 2015;70(10):2718-24. https://doi.org/10.1093/jac/ dkv185 PMID: 26142479

48. Saliba P, Hornero A, Cuervo G, Grau I, Jimenez E, García D, et al. Mortality risk factors among non-ICU patients with nosocomial vascular catheter-related bloodstream infections: a prospective cohort study. J Hosp Infect. 2018;99(1):48-54. https://doi.org/10.1016/j.jhin.2017.11.002 PMID: 29128346

49. Salmanov AG, Vdovychenko SY, Litus OI, Litus VI, Bisyuk YA, Bondarenko TM, et al. Prevalence of health care-associated infections and antimicrobial resistance of the responsible pathogens in Ukraine: Results of a multicenter study (20142016). Am J Infect Control. 2019;47(6):e15-20. https://doi. org/10.1016/j.ajic.2019.03.007 PMID: 31000318
50. Sante L, Aguirre-Jaime A, Miguel MA, Ramos MJ, Pedroso Y, Lecuona M. Epidemiological study of secondary bloodstream infections: The forgotten issue. J Infect Public Health. 2019;12(1):37-42. https://doi.org/10.1016/j.jiph.2018.08.011 PMID: 30266540

51. Venturini E, Montagnani C, Benni A, Becciani S, Biermann KP, De Masi S, et al. Central-line associated bloodstream infections in a tertiary care children's University hospital: a prospective study. BMC Infect Dis. 2016;16(1):725. https://doi. org/10.1186/s12879-016-2061-6 PMID: 27903240

52. Virano S, Scolfaro C, Garazzino S, De Intinis C, Ghisetti $V$, Raffaldi I, et al. Medical care related laboratoryconfirmed bloodstream infections in paediatrics. Infez Med. 2015;23(2):117-24. PMID: 26110291

53. Atici S, Soysal A, Kepenekli Kadayifci E, Karaaslan A, Akkoç $G$, Yakut N, et al. Healthcare-associated infections in a newly opened pediatric intensive care unit in Turkey: Results of four-year surveillance. J Infect Dev Ctries. 2016;10(3):254-9. https://doi.org/10.3855/jidc.7517 PMID: 27031457

54. Atilla A, Doğanay Z, Kefeli Çelik H, Demirağ MD, S Kiliç S. Central line-associated blood stream infections: characteristics and risk factors for mortality over a 5.5-year period. Turk J Med Sci. 2017;47(2):646-52. https://doi.org/10.3906/sag-1511-29 PMID: 28425261

55. Bonnet V, Dupont H, Glorion S, Aupée M, Kipnis E, Gérard JL, et al. Influence of bacterial resistance on mortality in intensive care units: a registry study from 2000 to 2013 (IICU Study). J Hosp Infect. 2019;102(3):317-24. https://doi.org/10.1016/j. jhin.2019.01.011 PMID: 30659869

56. Candevir A, Kurtaran B, Kibar F, Karakoc E, Aksu H, Tasova Y. Invasive device-associated nosocomial infections of a teaching hospital in Turkey; four years' experience. Turk J Med Sci. 2011;41:(1)137-47.

57. Cevik S, Bosnak V, Namiduru M, Karaoglan I, Mete A. Invasive device-associated hospital infection rates, etiological agents, and their antibiotic susceptibilities in the medical intensive care unit of a university hospital in Turkey. Turk J Med Sci. 2013;43(1)33-8.

58. Culshaw N, Glover G, Whiteley C, Rowland K, Wyncoll D, Jones $A$, et al. Healthcare-associated bloodstream infections in critically ill patients: descriptive cross-sectional database study evaluating concordance with clinical site isolates. Ann Intensive Care. 2014;4(1):34. https://doi.org/10.1186/s13613014-0034-8 PMID: 25593750

59. Custovic A, Smajlovic J, Tihic N, Hadzic S, Ahmetagic S, Hadzagic H. Epidemiological monitoring of nosocomial infections caused by acinetobacter baumannii. Med Arh. 2014;68(6):402-6. https://doi.org/10.5455/ medarh.2014.68.402-406 PMID: 25648217

6o. De Santis V, Gresoiu M, Corona A, Wilson AP, Singer M. Bacteraemia incidence, causative organisms and resistance patterns, antibiotic strategies and outcomes in a single university hospital ICU: continuing improvement between 2000 and 2013. J Antimicrob Chemother. 2015;70(1):273-8. https:// doi.org/10.1093/jac/dku338 PMID: 25190722

61. Deptuła A, Trejnowska E, Dubiel G, Żukowski M, MisiewskaKaczur A, Ozorowski T, et al. Prevalence of healthcareassociated infections in Polish adult intensive care units: summary data from the ECDC European Point Prevalence Survey of Hospital-associated Infections and Antimicrobial Use in Poland 2012-2014. J Hosp Infect. 2017;96(2):145-50. https:// doi.org/10.1016/j.jhin.2016.12.020 PMID: 28173962

62. Djordjevic Z, Jankovic S, Gajovic O, Djonovic N, Folic N, Bukumiric Z. Hospital infections in a neurological intensive care unit: incidence, causative agents and risk factors. J Infect Dev Ctries. 2012;6(11):798-805. https://doi.org/10.3855/ jidc.2659 PMID: 23277505

63. Erayman I, Erdi M, Kalkan E, Karatas Y, Kaya B, Keskin F, et al. Evaluation of nosocomial infections and related risk factors in a neurosurgery intensive care unit. Int J Clin Exp Med. 2016;9:(4):7334-8.

64. Geffers C, Gastmeier P. Nosocomial infections and multidrugresistant organisms in Germany: epidemiological data from KISS (the Hospital Infection Surveillance System). Dtsch Arztebl Int. 2011;108(6):87-93. https://doi.org/10.3238/ arztebl.2011.0087 PMID: 21373275

65. Inan A, Ozgültekin A, Akcay SS, Engin DO, Turan G, Ceran N, et al. Alterations in bacterial spectrum and increasing resistance rates in isolated microorganisms from device-associated infections in an intensive care unit of a teaching hospital in Istanbul (2004-2010). Jpn J Infect Dis. 2012;65(2):146-51. PMID: 22446122

66. Iordanou S, Middleton N, Papathanassoglou E, Raftopoulos V. Surveillance of device associated infections and mortality in a major intensive care unit in the Republic of Cyprus. BMC Infect Dis. 2017;17(1):607. https://doi.org/10.1186/s12879-017-27042 PMID: 28877671 
67. Kepenekli E, Soysal A, Yalindag-Ozturk N, Ozgur O, Ozcan I, Devrim I, et al. Healthcare-associated infections in pediatric intensive care units in Turkey: a national point-prevalence survey. Jpn J Infect Dis. 2015;68(5):381-6. https://doi. org/10.7883/yoken.JJID.2014.385 PMID: 25791987

68. Kołpa M, Wataszek M, Gniadek A, Wolak Z, Dobroś W. Incidence, microbiological profile and risk factors of healthcare-associated infections in intensive care units: A 10 year observation in a provincial hospital in southern Poland. Int J Environ Res Public Health. 2018;15(1):112. https://doi. org/10.3390/ijerph15010112 PMID: 29324651

69. Kostakoğlu U, Saylan S, Karataş M, İskender S, Aksoy F, Yılmaz $G$. Cost analysis and evaluation of nosocomial infections in intensive care units. Turk J Med Sci. 2016;46(5):1385-92. https://doi.org/10.3906/sag-1504-106 PMID: 27966302

70. Kouni S, Tsolia M, Roilides E, Dimitriou G, Tsiodras S, Skoutelis $A$, et al. Establishing nationally representative central line-associated bloodstream infection surveillance data for paediatric patients in Greece. J Hosp Infect. 2019;101(1):53-9. https://doi.org/10.1016/j.jhin.2018.07.032 PMID: 30059747

71. Djuric O, Markovic-Denic L, Jovanovic B, Bumbasirevic V. High incidence of multiresistant bacterial isolates from bloodstream infections in trauma emergency department and intensive care unit in Serbia. Acta Microbiol Immunol Hung. 2019;66(3):30725. https://doi.org/10.1556/030.66.2019.007 PMID: 30786727

72. Öncül O, Öksüz S, Acar A, Ülkür E, Turhan V, Uygur F, et al. Nosocomial infection characteristics in a burn intensive care unit: analysis of an eleven-year active surveillance. Burns. 2014;40(5):835-41. https://doi.org/10.1016/j. burns.2013.11.003 PMID: 24296064

73. Ong DS, Bonten MJ, Safdari K, Spitoni C, Frencken JF, Witteveen $E$, et al. Epidemiology, management, and risk-adjusted mortality of ICU-acquired enterococcal bacteremia. Clin Infect Dis. 2015;61(9):1413-20. https://doi.org/10.1093/cid/civ560 PMID: 26179013

74. Orsi GB, Giuliano S, Franchi C, Ciorba V, Protano C, Giordano $A$, et al. Changed epidemiology of ICU acquired bloodstream infections over 12 years in an Italian teaching hospital. Minerva Anestesiol. 2015;81(9):980-8. PMID: 25411769

75. Salmanov A, Litus V, Vdovychenko S, Litus O, Davtian L, Ubogov S, et al. Healthcare-associated infections in intensive care units. Wiad Lek. 2019;72(5) 5 CZ 2;963-9. https://doi. org/10.36740/WLek201905201 PMID: 31175725

76. Schwab F, Geffers C, Behnke M, Gastmeier P. ICU mortality following ICU-acquired primary bloodstream infections according to the type of pathogen: A prospective cohort study in 937 Germany ICUs (2006-2015). PLoS One. 2018;13(3):e0194210. https://doi.org/10.1371/journal. pone.0194210 PMID: 29518133

77. Süner A, Karaoğlan I, Mete AO, Namiduru M, Boşnak V, Baydar I. Assessment of bloodstream infections and risk factors in an intensive care unit. Turk J Med Sci. 2015;45(6):1243-50. https://doi.org/10.3906/sag-1303-41 PMID: 26775377

78. Sutcu M, Akturk H, Acar M, Salman N, Aydın D, Akgun Karapınar B, et al. Impact of vancomycin-resistant enterococci colonization in critically ill pediatric patients. Am J Infect Control. 2016;44(5):515-9. https://doi.org/10.1016/j. ajic.2015.11.026 PMID: 26781220

79. Tomaszewski D, Rybicki Z, Duszyńska W. The Polish Prevalence of Infection in Intensive Care (PPIC): A one day point prevalence multicenter study. Adv Clin Exp Med. 2019;28(7):907-12. https://doi.org/10.17219/acem/94147 PMID: 30986000

80. Viderman D, Brotfain E, Khamzina Y, Kapanova G, Zhumadilov $A$, Poddighe D. Bacterial resistance in the intensive care unit of developing countries: Report from a tertiary hospital in Kazakhstan. J Glob Antimicrob Resist. 2019;17:35-8. https:// doi.org/10.1016/j.jgar.2018.11.010 PMID: 30448518

81. Viderman D, Khamzina Y, Kaligozhin Z, Khudaibergenova M, Zhumadilov A, Crape B, et al. An observational case study of hospital associated infections in a critical care unit in Astana, Kazakhstan. Antimicrob Resist Infect Control. 2018;7(1):57. https://doi.org/10.1186/s13756-018-0350-0 PMID: 29713464

82. Wałaszek M, Różańska A, Bulanda M, Wojkowska-Mach JAlarming results of nosocomial bloodstream infections surveillance in Polish intensive care units. Przegl Epidemiol. 2018;72(1):33-44. PMID: 29667378

83. Walaszek M, Rozanska A, Bulanda M, Wojkowska-Mach J. Epidemiology of healthcare-associated infections in Polish intensive care. A multicenter study based on active surveillance. Biomed Pap Med Fac Univ Palacky Olomouc Czech Repub. 2018;162(3):190-7. https://doi.org/10.5507/ bp.2018.006 PMID: 29795542

84. Yetkin F, Yakupogullari Y, Kuzucu C, Ersoy Y, Otlu B, Colak C, et al. Pathogens of intensive care unit-acquired infections and their antimicrobial resistance: a 9-year analysis of data from a university hospital. Jundishapur J Microbiol. 2018;11(10):e67716. https://doi.org/10.5812/jjm.67716

85. Yoğun Ç, Ünitesindeki B, Enfeksiyonlarının H, Celiloglu C, Tolunay O, Sucu A, et al. Assessment of healthcare-associated infections in the pediatric intensive care unit. J Pediatr Inf.2017;11(3):113-8. https://doi.org/10.5578/ced.201733

86. Baier C, Pirr S, Ziesing S, Ebadi E, Hansen G, Bohnhorst B, et al. Prospective surveillance of bacterial colonization and primary sepsis: findings of a tertiary neonatal intensive and intermediate care unit. J Hosp Infect. 2019;102(3):325-31. https://doi.org/10.1016/j.jhin.2019.01.021 PMID: 30716339

87. Bolat F, Uslu S, Bolat G, Comert S, Can E, Bulbul A, et al. Healthcare-associated infections in a Neonatal Intensive Care Unit in Turkey. Indian Pediatr. 2012;49(12):951-7. https://doi. org/10.1007/S13312-012-0249-4 PMID: 22791673

88. Crivaro V, Bogdanović L, Bagattini M, Iula VD, Catania M, Raimondi F, et al. Surveillance of healthcare-associated infections in a neonatal intensive care unit in Italy during 2006-2010. BMC Infect Dis. 2015;15(1):152. https://doi. org/10.1186/s12879-015-0909-9 PMID: 25885702

89. Cura C, Ozen M, Akaslan Kara A, Alkan G, Sesli Cetin E. Health care-associated infection surveillance in a tertiary neonatal intensive care unit: A prospective clinical study after moving to a new building. Am J Infect Control. 2016;44(1):80-4. https:// doi.org/10.1016/j.ajic.2015.07.032 PMID: 26320701

90. Djordjevic ZM, Markovic-Denic L, Folic MM, Igrutinovic Z, Jankovic SM. Health care-acquired infections in neonatal intensive care units: risk factors and etiology. Am J Infect Control. 2015;43(1):86-8. https://doi.org/10.1016/j. ajic.2014.10.005 PMID: 25564130

91. Sadowska-Krawczenko I, Jankowska A, Kurylak A. Healthcareassociated infections in a neonatal intensive care unit. Arch Med Sci. 2012;8(5):854-8. https://doi.org/10.5114/ aoms.2012.31412 PMID: 23185195

92. Verstraete E, Boelens J, De Coen K, Claeys G, Vogelaers D, Vanhaesebrouck P, et al. Healthcare-associated bloodstream infections in a neonatal intensive care unit over a 20-year period (1992-2011): trends in incidence, pathogens, and mortality. Infect Control Hosp Epidemiol. 2014;35(5):511-8. https://doi.org/10.1086/675836 PMID: 24709719

93. Yalaz M, Altun-Köroğlu O, Ulusoy B, Yildiz B, Akisu M, Vardar F, et al. Evaluation of device-associated infections in a neonatal intensive care unit. Turk J Pediatr. 2012;54(2):128-35. PMID: 22734298

94. Guembe M, Pérez-Granda MJ, Capdevila JA, Barberán J, Pinilla B, Martín-Rabadán P, et al. Nationwide study on peripheralvenous-catheter-associated-bloodstream infections in internal medicine departments. J Hosp Infect. 2017;97(3):260-6. https://doi.org/10.1016/j.jhin.2017.07.008 PMID: 28716670

95. Karadağ Geçgel S, Demircan N. The epidemiology of pathogen microorganisms in hospital acquired infections. Int J Clin Exp Med. 2016;9:(11):22310-6.

96. Kołpa M, Wałaszek M, Różańska A, Wolak Z, Wójkowska-Mach J. Epidemiology of surgical site infections and non-surgical infections in neurosurgical Polish patients-Substantial changes in 2003-2017. Int J Environ Res Public Health. 2019;16(6):911. https://doi.org/10.339o/ijerph16060911 PMID: 30871283

97. Kuzdan C, Soysal A, Culha G, Altinkanat G, Soyletir G, Bakir $M$. Three-year study of health care-associated infections in a Turkish pediatric ward. J Infect Dev Ctries. 2014;8(11):1415-20. https://doi.org/10.3855/jidc.3931 PMID: 25390054

98. Tsitsopoulos PP, Iosifidis E, Antachopoulos C, Anestis DM, Karantani E, Karyoti A, et al. Nosocomial bloodstream infections in neurosurgery: a 10-year analysis in a center with high antimicrobial drug-resistance prevalence. Acta Neurochir (Wien). 2016;158(9):1647-54. https://doi.org/10.1007/so0701. 016-2890-5 PMID: 27452903

99. Garner JS, Jarvis WR, Emori TG, Horan TC, Hughes JM. CDC definitions for nosocomial infections, 1988. Am J Infect Control. 1988;16(3):128-40. https://doi.org/10.1016/01966553(88)90053-3 PMID: 2841893

100. Horan TC, Andrus M, Dudeck MA. CDC/NHSN surveillance definition of health care-associated infection and criteria for specific types of infections in the acute care setting. Am J Infect Control. 2008;36(5):309-32. https://doi.org/10.1016/j. ajic.2008.03.002 PMID: 18538699

101. Ott E, Saathoff S, Graf K, Schwab F, Chaberny IF. The prevalence of nosocomial and community acquired infections in a university hospital: an observational study. Dtsch Arztebl Int. 2013;110(31-32):533-40. https://doi.org/10.3238/ arztebl.2013.0533 PMID: 24069074

102. Russo PL, Stewardson AJ, Cheng AC, Bucknall T, Mitchell $B G$. The prevalence of healthcare associated infections among adult inpatients at nineteen large Australian acute-care public hospitals: a point prevalence survey. Antimicrob Resist Infect 
Control. 2019;8(1):114. https://doi.org/10.1186/s13756-0190570-y PMID: 31338161

103. Huerta-Gutiérrez R, Braga L, Camacho-Ortiz A, Díaz Ponce H, García-Mollinedo L, Guzmán-Blanco M, et al. One-day point prevalence of healthcare-associated infections and antimicrobial use in four countries in Latin America. Int J Infect Dis. 2019;86:157-66. https://doi.org/10.1016/j. ijid.2019.06.016 PMID: 31229613

104. Magill SS, O’Leary E, Janelle SJ, Thompson DL, Dumyati G, Nadle J, et al. Changes in prevalence of health care-associated infections in U.S. hospitals. N Engl ] Med. 2018;379(18):1732-44. https://doi.org/10.1056/ NEJMoa1801550 PMID: 30380384

105. Chen Y, Zhao JY, Shan X, Han XL, Tian SG, Chen FY, et al. A point-prevalence survey of healthcare-associated infection in fifty-two Chinese hospitals. J Hosp Infect. 2017;95(1):105-11. https://doi.org/10.1016/j.jhin.2016.08.010 PMID: 28007308

106. Centers for Disease Control and Prevention (CDC). 2019 national and state healthcare-associated infections (HAI) progress report. Atlanta: CDC; 2021. [Accessed: 26 Oct 2021]. Available from: https://arpsp.cdc.gov/profile/ national-progress/united-states

107.Wang J, Liu F, Tartari E, Huang J, Harbarth S, Pittet D, et al. The Prevalence of healthcare-associated infections in mainland China: a systematic review and meta-analysis. Infect Control Hosp Epidemiol. 2018;39(6):701-9. https://doi.org/10.1017/ ice.2018.60 PMID: 29655388

108. Mendes RE, Castanheira M, Farrell DJ, Flamm RK, Sader HS, Jones RN. Longitudinal (2001-14) analysis of enterococci and VRE causing invasive infections in European and US hospitals, including a contemporary (2010-13) analysis of oritavancin in vitro potency. Antimicrob Chemother. 2016;71(12):3453-8. https://doi.org/10.1093/jac/dkw319 PMID: 27609052

109. Kritsotakis El, Kontopidou F, Astrinaki E, Roumbelaki M, Ioannidou E, Gikas A. Prevalence, incidence burden, and clinical impact of healthcare-associated infections and antimicrobial resistance: a national prevalent cohort study in acute care hospitals in Greece. Infect Drug Resist. 2017;10:31728. https://doi.org/10.2147/IDR.S147459 PMID: 29066921

110. Mancini A, Verdini D, La Vigna G, Recanatini C, Lombardi FE, Barocci S. Retrospective analysis of nosocomial infections in an Italian tertiary care hospital. New Microbiol. 2016;39(3):197205. PMID: 27284985

111. Metsini A, Vazquez M, Sommerstein R, Marschall J, Voide C, Troillet N, et al. Point prevalence of healthcare-associated infections and antibiotic use in three large Swiss acute-care hospitals. Swiss Med Wkly. 2018;148(17-18):W14617. PMID: 29698542

112.European Centre for Disease Prevention and Control (EDCD). Point prevalence survey of healthcare associated infections and antimicrobial use in European acute care hospitals. Stockholm: ECDC; 2013. Available from: https://www.ecdc. europa.eu/en/publications-data/point-prevalence-surveyhealthcare-associated-infections-and-antimicrobial-use-o

113. European Centre for Disease Prevention and Control (ECDC). Point prevalence survey of healthcare-associated infections and antimicrobial use in European acute care hospitals 20112012. Stockholm: ECDC; 2013. Available from: https://www. ecdc.europa.eu/en/publications-data/point-prevalence-surveyhealthcare-associated-infections-and-antimicrobial-use-o

114. European Centre for Disease Prevention and Control (ECDC). Healthcare-associated infections acquired in intensive care units - Annual Epidemiological Report for 2017. Stockholm: ECDC; 2019. Available from: www.ecdc.europa.eu/en/ publications-data/healthcare-associated-infections-intensivecare-units-annual-epidemiological-1

115. Huang L, Zhang R, Hu Y, Zhou H, Cao J, Lv H, et al. Epidemiology and risk factors of methicillin-resistant Staphylococcus aureus and vancomycin-resistant enterococci infections in Zhejiang China from 2015 to 2017. Antimicrob Resist Infect Control. 2019;8(1):90. https://doi.org/10.1186/ S13756-019-0539-x PMID: 31164979

116. Hu F, Zhu D, Wang F, Wang M. Current status and trends of antibacterial resistance in China. Clin Infect Dis. 2018;67(2) suppl_2;S128-34. https://doi.org/10.1093/cid/ciy657 PMID: 30423045

117. Japan NIS. (JANIS). Annual open report 2018 (all facilities) Tokyo: JANIS; 2019. Available from: https://janis.mhlw.go.jp/ english/report/open_report/2018/3/1/ken_Open_Report_ Eng_201800_clsi2012.pdf

118. Kim EJ, Kwak Y, Kim T, Lee MS, Lee S-O, Kim S, et al. Korean national healthcare-associated infections surveillance system, intensive care unit module report: summary of data from July 2017 through June 2018. Korean J of Healthc Assoc Infect Control and Prev.2019;24(2):69. https://doi.org/10.14192/ kjicp.2019.24.2.69
119. Taiwan Centers for Disease Control Control (TCfDC). Annual report of nosocomial infections surveillance system 2016. Taipei: TCfDC; 2016. Available from: https://www.cdc. gov/drugresistance/pdf/threats-report/2019-ar-threatsreport-508.pdf

120. Centers for Disease Control and Prevention (CDC). Antibiotic resistance threats in the United States, 2019. Atlanta: CDC; 2019. Available from: https://www.cdc.gov/drugresistance/ pdf/threats-report/2019-ar-threats-report-508.pdf

121.Pfaller MA, Cormican M, Flamm RK, Mendes RE, Jones RN. Temporal and geographic variation in antimicrobial susceptibility and resistance patterns of Enterococci: results from the SENTRY antimicrobial surveillance program, 19972016. Open Forum Infect Dis. 2019;6Suppl 1;S54-62. https:// doi.org/10.1093/ofid/ofy344 PMID: 30895215

122. Centers for Disease Control and Prevention (CDC). Antibiotic use in the United States, 2017: progress and opportunities. Atlanta: CDC; 2017. Available from: https://www.cdc.gov/ antibiotic-use/stewardship-report/pdf/stewardship-report.pdf

123. Allegranzi B, Bagheri Nejad S, Combescure C, Graafmans W, Attar H, Donaldson L, et al. Burden of endemic health-careassociated infection in developing countries: systematic review and meta-analysis. Lancet. 2011;377(9761):228-41. https://doi.org/10.1016/S0140-6736(10)61458-4 PMID: 21146207

124. Ayobami O, Willrich N, Harder T, Okeke IN, Eckmanns T, Markwart R. The incidence and prevalence of hospitalacquired (carbapenem-resistant) Acinetobacter baumannii in Europe, Eastern Mediterranean and Africa: a systematic review and meta-analysis. Emerg Microbes Infect. 2019;8(1):1747-59. https://doi.org/10.1080/22221751.2019.16 98273 PMID: 31805829

125. Markwart R, Saito H, Harder T, Tomczyk S, Cassini A, Fleischmann-Struzek C, et al. Epidemiology and burden of sepsis acquired in hospitals and intensive care units: a systematic review and meta-analysis. Intensive Care Med. 2020;46(8):1536-51. https://doi.org/10.1007/s00134-02006106-2 PMID: 32591853

126. Kritsotakis El, Kontopidou F, Astrinaki E, Roumbelaki M, Ioannidou E, Gikas A. Prevalence, incidence burden, and clinical impact of healthcare-associated infections and antimicrobial resistance: a national prevalent cohort study in acute care hospitals in Greece. Infect Drug Resist. 2017;10:317-28. https://doi.org/10.2147/IDR.S147459 PMID: 29066921

127. Hansen S, Zingg W, Ahmad R, Kyratsis Y, Behnke M, Schwab F, et al. Organization of infection control in European hospitals. J Hosp Infect. 2015;91(4):338-45. https://doi.org/10.1016/j. jhin.2015.07.011 PMID: 26542950

128. Werner G, Coque TM, Hammerum AM, Hope R, Hryniewicz W, Johnson A, et al. Emergence and spread of vancomycin resistance among enterococci in Europe. Euro Surveill. 2008;13(47):19046. https://doi.org/10.2807/ese.13.47.19046en PMID: 19021959

129. European Centre for Disease Prevention and Control (ECDC). Antimicrobial consumption in the EU/ EEA, annual epidemiological report for 2018 . Stockholm: ECDC; 2019. Available from: https:// www.ecdc.europa.eu/en/publications-data/ surveillance-antimicrobial-consumption-europe-2018

130. European Centre for Disease Prevention and Control (ECDC). Antimicrobial consumption database (ESAC-Net). Stockholm: ECDC; 2021. [Accessed: 5 Nov 2021]. Available from: https:// www.ecdc.europa.eu/en/antimicrobial-consumption/ surveillance-and-disease-data/database

131. Forstner C, Diab-Elschahawi M, Kivaranovic D, Graninger W, Mitteregger D, Macher M, et al. Non-linear significant relationship between use of glycopeptides and isolation of vancomycin-resistant Enterococcus species in a university hospital setting. Antimicrob Resist Infect Control. 2015;4(1):25. https://doi.org/10.1186/s13756-015-0064-5 PMID: 26078865

132. Fridkin SK, Edwards JR, Courval JM, Hill H, Tenover FC, Lawton $R$, et al. The effect of vancomycin and third-generation cephalosporins on prevalence of vancomycin-resistant enterococci in 126 U.S. adult intensive care units. Ann Intern Med. 2001;135(3):175-83. https://doi.org/10.7326/0003-4819135-3-200108070-00009 PMID: 11487484

133. Dahms RA, Johnson EM, Statz CL, Lee JT, Dunn DL, Beilman GJ. Third-generation cephalosporins and vancomycin as risk factors for postoperative vancomycin-resistant enterococcus infection. Arch Surg. 1998;133(12):1343-6. https://doi. org/10.1001/archsurg.133.12.1343 PMID: 9865653

134. Kritsotakis El, Christidou A, Roumbelaki M, Tselentis Y, Gikas A. The dynamic relationship between antibiotic use and the incidence of vancomycin-resistant Enterococcus: timeseries modelling of 7 -year surveillance data in a tertiary-care 
hospital. Clin Microbiol Infect. 2008;14(8):747-54. https://doi. org/10.1111/j.1469-0691.2008.02026.x PMID: 18727798

135. Remschmidt C, Behnke M, Kola A, Peña Diaz LA, Rohde AM, Gastmeier $\mathrm{P}$, et al. The effect of antibiotic use on prevalence of nosocomial vancomycin-resistant enterococci- an ecologic study. Antimicrob Resist Infect Control. 2017;6(1):95. https:// doi.org/10.1186/s13756-017-0253-5 PMID: 28924472

136. Agudelo Higuita NI, Huycke MM. Enterococcal disease, epidemiology, and implications for treatment. Boston: Massachusetts Eye and Ear Infirmary; 2014. Available from: https://www.ncbi.nlm.nih.gov/books/NBK190429

\section{License, supplementary material and copyright}

This is an open-access article distributed under the terms of the Creative Commons Attribution (CC BY 4.0) Licence. You may share and adapt the material, but must give appropriate credit to the source, provide a link to the licence and indicate if changes were made.

Any supplementary material referenced in the article can be found in the online version.

This article is copyright of the authors or their affiliated institutions, 2021. 